\title{
Intonasi Perasaan Senang Tuturan Bahasa Melayu Langkat dengan Menggunakan Metode Average
}

\author{
Emmy Erwina ${ }^{a, 1}$ \\ a Universitas Harapan Medan, Indonesia
}

Iemmyerwina8@gmail.com

Article info A B S T R A C T

Article history:

Received: 09-10-2020

Revised: 14-10-2020

Accepted:21-11-2020

Keywords:

Average Method

Intonation Malay Language,

Happy Emotions,
This study describes the intonation pattern of Langkat Malay speech in happy emotions. This research is an experimental phonetic study to experiment with happy speech among the ordinary people and the aristocracy in Tanjungpura, Langkat Regency, North Sumatra. Data obtained from the utterances of six informants and 40 respondents who were tested. This study uses the acoustic-phonetic theory and Praat program. The target speech in the study for happy emotions is [sonã $\dot{\eta}$ benã amba mondeñãr kabria jo]. The research method used in this research is by using the Average method. The data obtained will be processed to determine how much the intonation of happy feelings in Malay language utterances is still used. The results showed that the average person's emotional content was higher than among the aristocrats, and there was a difference in the duration of the pronunciation. By making changes to happy emotional speech, namely decreasing several sts, the result still shows the meaning of happy emotions. Even when it is raised a few sts, the result becomes a pleasing emotional meaning.

Penelitian ini mendeskripsikan pola intonasi tuturan bahasa Melayu Langkat dalam emosi senang. Penelitian ini merupakan kajian fonetik eksperimental, yaitu melakukan percobaan berupa tuturan senang pada kalangan orang kebanyakan dan kaum bangsawan yang berada di Tanjungpura, Kabupaten Langkat, Sumatera Utara. Data diperoleh dari tuturan enam informan dan 40 responden yang diujipersepsikan. Penelitian ini menggunakan teori fonetik akustik dan program Praat.Tuturan target dalam penelitian untuk emosi senang adalah [sənãń benã amba məndeńãr kabarńã jo]. Metode penelitian yang dilakukan pada penelitian ini yaitu dengan menggunakan metode Average. Data yang didapatkan akan diolah sehingga mendapatkan presentase seberapa besar intonasi perasaan senang pada tuturan bahasa melayu langkat yang masih digunakan. Hasil penelitian menunjukkan bahwa tuturan emosi senang dari kalangan orang kebanyakan lebih tinggi dibandingkan dengan kalangan kaum bangsawan dan terdapat perbedaan durasi pada saat pengucapan. Dengan melakukan perubahan tuturan emosi senang, yaitu menurunkan beberapa st hasilnya masih tetap menunjukkan makna emosi senang, tetapi ketika dinaikkan beberapa st maka, hasilnya menjadi makna emosi sangat senang.

Copyright (๑) 2020 Institut Agama Islam Negeri Syekh Nurjati Cirebon. All rights reserved. 


\section{PENDAHULUAN}

Berbicara mengenai suprasegmental, tentu berkaitan dengan bunyi bahasa karena bunyi bahasa dibedakan antara bunyi segmental dan suprasegmental. Bunyi segmental adalah bunyi yang terdapat secara berurutan, sedangkan bunyi suprasegmental adalah bunyi bahasa yang menyertai bunyi segmental tersebut (Oktavia, 2018). Runtunan bunyi merupakan arus ujaran yang sambungmenyambung dan terus-menerus yang diselingi oleh jeda, disertai dengan intensitas suara, frekuensi, serta durasi. Bunyi-bunyi vokal dan konsonan yang didengar di dalam arus ujaran disebut bunyi segmental, yaitu bunyi yang dapat disegmentasikan. Struktur melodis dan struktur temporal atau ritme adalah ciri akustik yang menyertai sebuah tuturan (Ardipal, 2015). Adapun bunyi yang tidak dapat disegmentasikan, seperti: cepat-lambat, kelantangan, tekanan, dan nada. Bunyi ini biasa disebut dengan suprasegmental atau prosodi.

Secara fisik bunyi bahasa manusia sangat variatif dan sukar diduga sehingga penelaahan terhadapnya selain memerlukan peralatan yang canggih juga membutuhkan pengamatan yang menyita waktu dan tenaga. Pemakaian alat-alat mutakhir, seperti sound spectrograph digital untuk ketepatan penganalisisan bunyi bahasa, mengisyaratkan bahwa seorang ahli penelitian bunyi bahasa harus mempunyai keterampilan yang khusus, profesional, dan peka terhadap perkembangan teknologi (Tarigan, 2018).

Cara bertutur, cara menulis, dan isyarat adalah cara untuk berkomunikasi di dalam masyarakat bahasa. Karakteristik tuturan yang mengandung kekeliruan inferensi percakapan dipilah ke dalam empat kelompok atas dasar situasi tutur, jenis tuturan, pelanggaran prinsip kerjasama, dan pelanggaran prinsip kesantunan (Alviah, 2014). Cara bertutur berhubungan dengan bunyi bahasa yang juga berhubungan dengan fonetik. Penelitian fonetik dibagi menjadi tiga subbidang utama, yaitu: 1) penelitian terhadap sistem alat yang menghasilkan bunyi bahasa serta proses yang berkaitan dalam menghasilkan bunyi yaitu fonetik artikulatori; 2) penelitian terhadap gelombang bunyi yang dihasilkan dari pengucapan dan sistem penyiaran gelombang melalui udara di sebut fonetik akustik, dan 3) penelitian terhadap pendengaran gelombang bunyi bahasa dan alat-alat pendengaran seperti telinga dan anggota-anggota lain yang terlibat dalam sistem pendengaran yaitu fonetik auditori (Lidwina, 2012).

Poegoeh \& Hamidah (2016) menyatakan bahwa penelitian terhadap penelitian emosi senang banyak dilakukan dari sudut pandang psikologi, antropologi, dan filsafat. Namun penelitian emosi senang yang dikaji dengan pendekatan fonetik akustik masih sangat langka dilakukan. Padahal emosi senang yang umumnya lahir dari tuturan suatu bahasa verbal perlu dilihat dari aspek frekuensi, durasi, dan intonasi ujaran dari tuturan emosi tersebut. Pada saat seorang penutur emosi, tentu akan menghasilkan frekuensi, durasi, dan intonasi ujaran yang berbeda dengan seseorang yang tidak dalam suasana emosi (Nadhiroh, 2015).

Semua bahasa di dunia ini, tentu mempunyai unsur emosi yang berkaitan dengan ucapan atau tuturan penuturnya (Handayani \& Nurwidawati, 2013). Tindak tutur menjadi dasar analisis aspek pragmatik yang lain seperti praanggapan, perikutan, implikatur percakapan, prinsip kerja sama, dan prinsip kesantunan (Handono, 2017). Dalam hal ini, tidak terkecuali bahasa Melayu dialek Langkat. Oleh karena itu, penelitian ini akan mendeskripsikan intonasi dan durasi tuturan bahasa Melayu Langkat pada emosi senang. Emosi senang mempunyai fungsi sebagai penanda atau ungkapan emosional yang mendorong perubahan suasana hati 
seseorang sehingga menyebabkan orang itu tertawa atau senang. Ekspresi emosi senang di dalam bahasa Melayu Langkat juga direalisasikan melalui unsur prosodi atau suprasegmental (Rahman, 2016).

Bahasa Melayu Langkat sebagai salah satu bahasa daerah di Indonesia yang digunakan khusus di Sumatera Utara tepatnya di Langkat, berfungsi sebagai alat komunikasi, pendukung kebudayaan, dan lambang identitas masyarakat Melayu Langkat (Zuhrah, 2016). Ketiga fungsi itu terealisasi dalam kegiatan-kegiatan anggota masyarakat dalam berkomunikasi antarsesama. Masyarakat Melayu terdiri atas dua golongan, yakni golongan bangsawan dan golongan kebanyakan (Nasir \& Hamzah, 2014).

Alasan pemilihan bahasa Melayu Langkat sebagai penelitian didasari oleh beberapa alasan. Pertama, alasan keberagaman latar belakang bahasa yang dimiliki oleh masyarakat. Jika diperhatikan dari latar belakang bahasa pertama yang dikuasai, masyarakat Melayu Langkat pada umumnya berlatar belakang bahasa Melayu, bahasa Karo, bahasa Indonesia, dan bahasa lainnya. Hal itu sesuai dengan profil sosiolinguistik Kabupaten Langkat, yang ditandai oleh terdapatnya bahasa Karo dan bahasa Batak sebagai bahasa daerah, yang dipakai oleh komunitas penutur pribumi di wilayahnya masing-masing. Selain itu, terdapat pula bahasa-bahasa daerah lain, yang dikuasai oleh penduduk yang merupakan pendatang dari pelbagai daerah dan akhirnya menetap di wilayah Langkat.

Kedua, karena peneliti sendiri merupakan suku bangsa Melayu, sehingga tidak ada hambatan emosional dan psikologis antara peneliti dan subyek yang diteliti. Dengan demikian, data yang diperoleh diharapkan merupakan data alamiah, akurat, konkret, dan bukan hasil rekayasa. Antara peneliti dengan informan dan responden saling mempercayai karena sudah saling mengenal dan saling percaya. Dengan keadaan seperti itu, peneliti mendapatkan kemudahan untuk melakukan pengecekan, konfirmasi, dan penggalian data secara lebih memadai agar beroleh data yang diharapkan. Ketiga, informan dan responden dapat dikondisikan untuk bersedia direkam suaranya serta bersedia mengisi kuesioner secara utuh, jujur, terbuka, dan sesuai dengan kenyataan. Hal itu turut dipertimbangkan mengingat kesediaan responden untuk mengisi kuesioner secara utuh dan lengkap sangat dibutuhkan dalam penjaringan data.

Perbedaan unsur eksternal itu, menyebabkan bahasa Melayu Langkat memiliki kecenderungan perbedaan kualitas prosodi. Kualitas prosodi bangsawan diduga berbeda dengan golongan kebanyakan. Diduga bahwa kualitas prosodi bahasa Melayu Langkat dari satu generasi ke generasi berikutnya menurun. Bahasa Melayu Langkat sebagai identitas diri dan pembentuk budaya harus dipertahankan oleh penuturnya agar bahasa Melayu dapat bertahan sampai akhir zaman, seperti pepatah mengatakan takkan hilang Melayu di bumi (Mulyani dkk, 2018). Generasi muda khususnya di Tanjung Pura kurang menguasai bahasa Melayu, seperti yang peneliti dapatkan ketika peneliti berkunjung ke Tanjung Pura untuk menjaring data (Adisaputera, 2009). Berbagai faktor menjadi penyebab penurunan ataupun pengikisan kompetensi bahasa Melayu Langkat. Pengaruh itu adalah pengaruh lingkungan di sekitar Tanjung Pura yang sudah banyak dipengaruhi oleh penduduk sekitar dan bukan penduduk asli suku Melayu, mereka suku-suku lain yang ada di Indonesia, seperti suku Jawa, Minang, dan Karo.

Intonasi merupakan sebuah unsur dalam tuturan yang dapat membantu seseorang ketika mengekspresikan sesuatu yang ada dalam hati atau perasaan 
dengan naik turunnya suara. Keberadaan intonasi memengaruhi makna suatu kalimat (Morrison \& Fyk, 2011). Di dalam bahasa Melayu Langkat, bunyi bahasa terdiri atas vokal dan konsonan sama dengan bunyi bahasa pada umumnya. Suciati \& Agung (2017) menyatakan bahwa jumlah fonem bahasa Melayu Langkat berjumlah 28 fonem yang terdiri atas 8 fonem vokal dan 20 fonem konsonan. Vokal

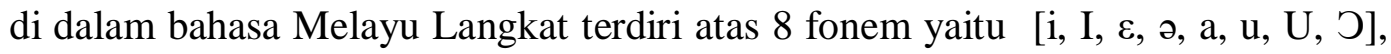
sedangkan konsonan di dalam bahasa Melayu Langkat terdiri atas 20 fonem yaitu [p, t, č, k, ?, b, d, j, g, f, s, h, m, n, í, y, l, r, w, j].

Emosi mempunyai peran yang penting dalam komunikasi sehari-hari. Kata emosi berasal dari bahasa Prancis emouvoir, yang berarti kegembiraan. Selain itu, emosi juga berasal dari bahasa Latin yaitu emovere, dari e-(varian eks) yang berarti "luar" dan movere "bergerak". Dalam Kamus Besar Bahasa Indonesia (2016) emosi mempunyai arti luapan perasaan yang berkembang dan surut dalam waktu singkat; keadaan dan reaksi psikologis dan fisiologis (seperti kegembiraan, kesedihan, keharuan, kecintaan), keberanian yang bersifat subjektif. Emosi adalah pengungkapan ekspresi yang selalu muncul dari dalam diri seseorang di luar kesadaran (Al-Baihaqi, 2015). Berbagai macam peristiwa selalu melibatkan emosi. Orang akan marah ketika diremehkan di hadapan publik, sedih karena berpisah dengan orang yang dikasihi, senang ketika mendapatkan hadiah yang diimpikan. Peristiwa-peristiwa yang terjadi di dalam kehidupan manusia memang selalu berkaitan dengan emosi. Dengan demikian, kehidupan manusia itu mempunyai warna yang berbeda. Berbagai ekspresi dalam merespons berbagai situasi yang dialami sesungguhnya memperkaya kehidupan.

Metode Average ini sama dengan rata-rata bergerak, tetapi nilai terbaru dalam deret berkala diberikan beban lebih besar untuk menghitung perkiraan (Alfarisi, 2017). Metode Average diberikan bobot yang berbeda untuk setiap data historis masa lalu yang tersedia, dengan asumsi bahwa data historis yang paling terakhir atau terbaru akan memiliki bobot lebih besar dibandingkan dengan data historis yang lama karena data yang paling terakhir atau terbaru merupakan data yang paling relevan untuk perkiraan (Gofur \& Widianti, 2015). Ardiana \& Loekito (2018) menyebutkan bahwa Metode Average merupakan metode yang mempunyai teknik pemberian bobot yang berbeda atas data yang tersedia dengan demikian bahwa data yang paling akhir adalah data yang paling relevan untuk peramaln se-hingga diberi bobot yang lebih besar. Metode ini digunakan jika terdapat data masa lalu merupakan data yang tidak memiliki unsur trend atau faktor musiman (Nurlifa \& Kusumadewi, 2017).

Pemilihan penelitian ini didasarkan atas asumsi bahwa di dalam masyarakat Melayu Langkat terdapat kelompok-kelompok sosial. Kelompok-kelompok sosial tersebut dalam berinteraksi sehari-hari berbeda dalam menuturkan atau mengungkapkan emosinya senang kepada seseorang. Diduga dalam pertuturan sehari-hari pola intonasi emosi kelompok bangsawan lebih rendah atau lebih halus dibandingkan dengan kelompok orang kebanyakan. Penelitian terhadap keberadaan bahasa ini relatif sedikit, khususnya terkait dengan penelitian intonasi emosi senang. Dari beberapa penelitian ini, belum ada yang khusus melakukan penelitian tentang intonasi emosi senang dalam tuturan bahasa Melayu Langkat tersebut. Hal ini tentu saja menjadi dorongan yang kuat untuk menemukan fenomena-fenomena menarik yang terkait dengan intonasi emosi senang pada tuturan pada bahasa Melayu Langkat. 


\section{METODE}

Data yang digunakan dalam penelitian ini, yaitu tuturan bahasa Melayu Langkat yang berdomisili di Tanjung Pura dan sekitarnya. Informan penelitian ini terdiri atas dua kelas sosial yang berbeda, yaitu kelas sosial bangsawan dan orang kebanyakan. Informan dalam penelitian ini berjumlah 6 orang yang terdiri atas 3 orang dari kelompok bangsawan dan 3 orang dari kelompok kebanyakan. Adapun usianya antara 20 tahun sampai dengan 55 tahun. Alasan memilih 6 orang sebagai informan karena alat ucap yang dimiliki masih baik atau artikulator yang lengkap. Teknik pengambilan informan menggunakan teknik purposive, yakni berdasarkan tujuan penelitian. Responden ditujukan kepada penutur bahasa Melayu Langkat sebanyak 40 orang terdiri atas 20 orang kelompok bangsawan dan 20 orang dari kelompok kebanyakan yang keseluruhannya dijadikan sebagai sampel atau total sampling.

Metode pengumpulan data dengan cara mengumpulkan data tuturan bahasa Melayu Langkat dari enam penutur/informan yang terbagi menjadi dua kelompok, yaitu kelompok bangsawan dan kelompok orang kebanyakan. Masing-masing penutur mengucapkan tiga tuturan yang terdiri atas tiga aspek emosi yaitu emosi marah, dengan tuturan targetnya Pedeh hati ambe ngeleh kelakuannya tang orang tua! 'Pedih hatiku melihat kelakuannya pada orang tua!' emosi sedih, Pereh kali atine, ia gugor dalam ngelakuka tugasnya 'Sedih sekali hati ini ia gugur dalam melakukan tugasnya' dan emosi senang, Senang bena, amba mendengar kabarnya yo. 'Senang benar mendengar kabar itu'.

Semua data direkam dengan menggunakan alat stereo cassette-recorder Sony WM-GX410 yang dilengkapi dengan head set mic kemudian dalam proses digitalisasi menggunakan program komputer. Dalam menganalisis data, dilakukan dengan beberapa tahap. Tahap yang pertama adalah proses digitalisasi. Pada tahap ini data yang direkam menggunakan kaset audio kemudian dialihkan ke format digital dalam bentuk sound wave- selanjutnya dipilih tuturan-tuturan yang akan dianalisis. Akhirnya data-data yang sudah terpilih itu akan diberi kode nama.

Pada tahap berikutnya adalah dengan melakukan pengukuran ciri akustik, yaitu dengan mengukur frekuensi dan durasi setiap tuturan dan mengekstrak hasil pengukuran itu ke dalam pangkalan data. Pengujian persepsi data tersebut dengan menghadirkan responden sebanyak 20 orang dari kalangan bangsawan dan 20 orang dari kalangan orang kebanyakan. Untuk uji persepsi ini disusun kuesioner atau lembar uji persepsi dengan menggunakan tabel yang terdiri atas kolom-kolom yang berisikan nomor, kode, dan data aspek emosi senang. Tahap selanjutnya adalah tahap uji statistik untuk mengetahui signifikan atau tidaknya ciri akustik hasil pengukuran. Pengukuran analisis statistik menggunakan program komputer SPSS (Statistics Package for Social Scientist) versi 17. Eksperimen dilakukan agar dapat membuktikan hipotesis penelitian ini.

Uji persepsi penelitian ini dilakukan dengan melibatkan 40 orang responden yang terdiri atas 20 orang dari kalangan kaum bangsawan dan 20 orang dari kalangan orang kebanyakan. Kaum bangsawan pula terdiri atas 10 orang laki-laki, dan 10 orang perempuan. Begitu pula dengan kalangan orang kebanyakan, yaitu 10 orang laki-laki dan 10 orang perempuan. Adapun modul uji persepsi yang digunakan adalah tipe skala Likert. Skala Likert dirancang untuk menguji tingkat kesetujuan atau degree of agreenees responden terhadap suatu pernyataan. Contohnya, tingkat kesetujuan itu pada umumnya dibagi atas lima tingkatan yang diberi bobot, yaitu (1) Sangat Tidak Setuju (2) Tidak Setuju (3) Cukup Setuju (4) 
Setuju (5) dan Sangat Setuju, kemudian responden diminta untuk melingkari nomor yang sesuai dengan penilaian responden tersebut.

Skala Likert termasuk dalam skala interval dan perbedaan dalam antara dua poin dalam skala mempunyai nilai yang sama. Dengan pengukuran ini dapat dengan mudah mengukur tingkat emosi senang ketika mengakumulasinya. Pilihan jawaban yang harus responden contreng ketika memilih jawaban untuk emosi senang adalah (1) Sangat Tidak Senang, (2) Tidak Senang, (3) Cukup Senang, (4) Senang, dan (5) Sangat Senang

Hasil dari uji ekperimen pada uji persepsi penelitian ini mengambil data dengan Method Average atau metode rerata dari data ekperimen pada uji persepsi ini. Pada peneliti ini dapat dihitung berapa tingkat intonasi perasaan senang para penutur bahasa Melayu Langkat yang berdomisili di Tanjung Pura. Penelitian ini sangat dibutuhkan bukan hanya untuk mengukur tingkat intonasi para penutur, tetapi nantinya dapat menganalisis jumlah tuturan pada intonasi perasaan senang para penutur bahasa Melayu Langkat yang berdomisili di Tanjung Pura. Tanpa menggunakan survey dan Method Average, data yang diteliti akan cukup sulit untuk dipastikan kebenaran dan kelengkapannya.

\section{HASIL DAN PEMBAHASAN}

Berikut ini data yang berhasil diperoleh.

Tabel 1. Data Uji Persepsi

\begin{tabular}{|c|c|c|c|c|c|c|c|c|c|c|c|c|c|}
\hline \multirow[t]{2}{*}{ Kontur } & $\begin{array}{c}\text { Kode } \\
\text { Stimulus }\end{array}$ & \multicolumn{5}{|c|}{ Skor } & \multirow[t]{2}{*}{$\begin{array}{cc}\text { Total } \\
\text { Responden } \\
\end{array}$} & \multicolumn{5}{|c|}{ Nilai } & $\begin{array}{l}\text { Total } \\
\text { Nilai } \\
\end{array}$ \\
\hline & & STS & TS & CS & $\mathbf{S}$ & SS & & STS & TS & CS & $\mathbf{S}$ & SS & \\
\hline \multirow[t]{2}{*}{ Emosi } & $\mathrm{CO}$ & 2 & 4 & 12 & 11 & 11 & 40 & 2 & 8 & 36 & 44 & 55 & 145 \\
\hline & $\mathrm{C} 00$ & 1 & 2 & 6 & 27 & 4 & 40 & 1 & 4 & 18 & 108 & 20 & 151 \\
\hline
\end{tabular}

Tabel 1 menunjukkan hasil uji persepsi emosi senang terhadap 40 responden yang terdiri atas 20 kalangan kaum bangsawan dan 20 kalangan orang kebanyakan.

Tabel 2. Hasil Analisis Data

\begin{tabular}{|c|c|c|c|c|c|c|c|}
\hline & \multicolumn{5}{|c|}{ Paired Differences } & \multirow{3}{*}{ df } & \multirow{3}{*}{$\begin{array}{l}\text { Sig. (2- } \\
\text { tailed) }\end{array}$} \\
\hline & \multirow[t]{2}{*}{ Mean } & \multirow[t]{2}{*}{$\begin{array}{c}\text { Std. } \\
\text { Deviation }\end{array}$} & \multirow[t]{2}{*}{$\begin{array}{l}\text { Std. Error } \\
\text { Mean }\end{array}$} & \multicolumn{2}{|c|}{$\begin{array}{c}95 \% \text { Confidence } \\
\text { Interval of the } \\
\text { Difference }\end{array}$} & & \\
\hline & & & & Lower & Upper & & \\
\hline Pair 1 C0-C00 & -0.15 & 1.406 & 0.222 & -0.59967 & 0.299671 & -0.6747239 & 0.508831 \\
\hline
\end{tabular}

Tabel 2 menunjukkan adanya perbedaan signifikansi antara stimulus C0 dengan stimulus $\mathrm{C} 00$ pada taraf ${ }^{\circ}=0,05$ dan df $\mathrm{n}-1$. Tabel ini menunjukkan bahwa $t_{\text {hitung }}(0,6747)<t_{\text {tabel }}(2,02)$ dengan probabilitas $(p) 0,503$. Hal ini menunjukkan bahwa perbedaan stimulus CO dengan stimulus COO tidak signifikan. Ini menunjukkan bahwa nada asli tuturan emosi senang yang dituturkan oleh penutur kalangan kaum bangsawan dan kalangan orang kebanyakan yang dipersepsikan responden tidak menunjukkan perbedaan persepsi emosi senang yang signifikan. Nada asli tuturan emosi senang yang dituturkan oleh penutur kalangan kaum bangsawan dan kalangan orang kebanyakan memiliki bentuk yang sama, yaitu kontur yang naik dan menurun atau deklinasi, tetapi dengan perbedaan frekuensi 
yang signifikan. Tuturan emosi senang dari kalangan orang kebanyakan lebih tinggi dibandingkan dengan kalangan kaum bangsawan dan terdapat perbedaan durasi pada saat pengucapan.

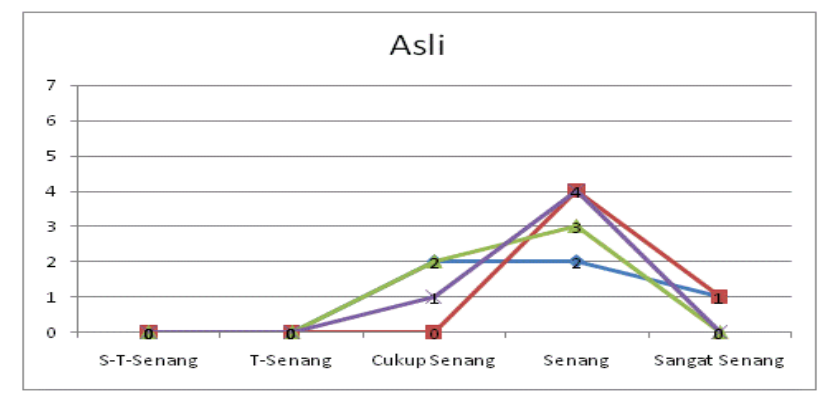

\section{Gambar 1. Uji Persepsi Tuturan Asli Bangsawan}

Gambar 1 merupakan uji persepsi responden dengan intonasi asli tuturan emosi senang kaum bangsawan. Gambar 1 menunjukkan bahwa pada kalimat senang dengan intonasi asli yang diperdengarkan, hampir seluruh responden menunjukkan persepsi dengan emosi senang.

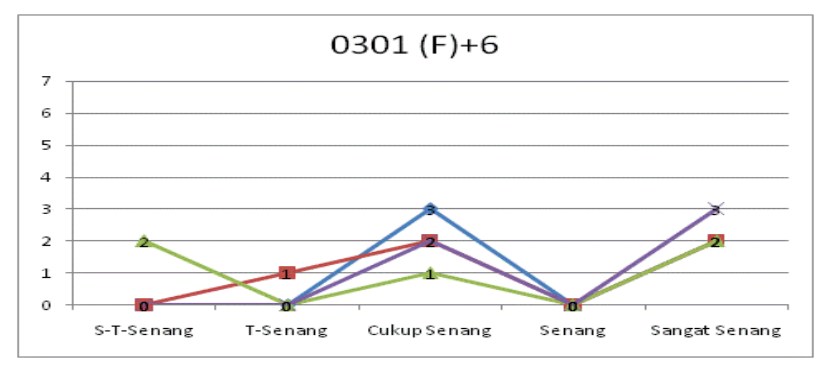

\section{Gambar 2. Uji Persepsi Tuturan Bangsawan dengan Intonasi +6}

Gambar 2 merupakan uji persepsi responden dengan intonasi +6 st tuturan emosi senang kaum Bangsawan. Gambar 2 ini menunjukkan bahwa setelah frekuensi suara dinaikkan 6 st $(0301 \mathrm{~B}(\mathrm{~F})+6)$ dan diperdengarkan, terlihat tanggapan kelompok responden masuk kepada kategori emosi sangat senang. Pada tingkat ini menunjukkan bahwa persepsi responden berada pada tingkat emosi sangat senang. Sebanyak 9 responden memberikan persepsi sangat senang, sedangkan 2 responden memberikan persepsi sangat tidak senang.

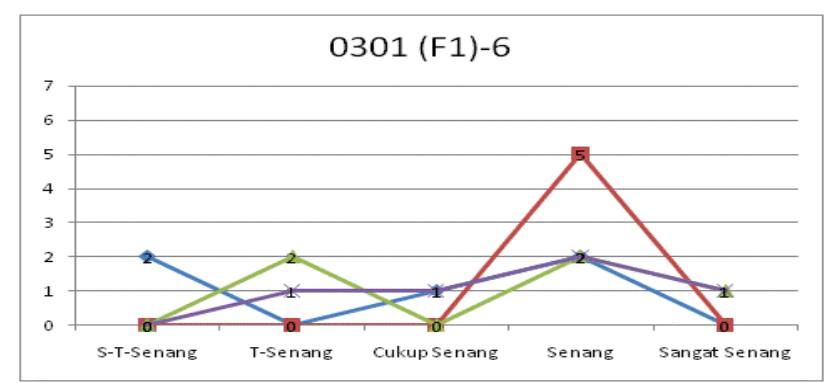

\section{Gambar 3. Uji Persepsi Tuturan Bangsawan dengan Intonasi -6}

Gambar 3 merupakan uji persepsi responden dengan intonasi -6 st. Gambar 3 menunjukkan tuturan emosi senang dengan perubahan intonasi yang diturunkan 6 st (0301 G (F)-6). Hasilnya sebanyak 8 responden memberikan persepsi senang, 8 
responden memberikan persepsi tidak senang, sedangkan 2 responden memberikan persepsi sangat senang.

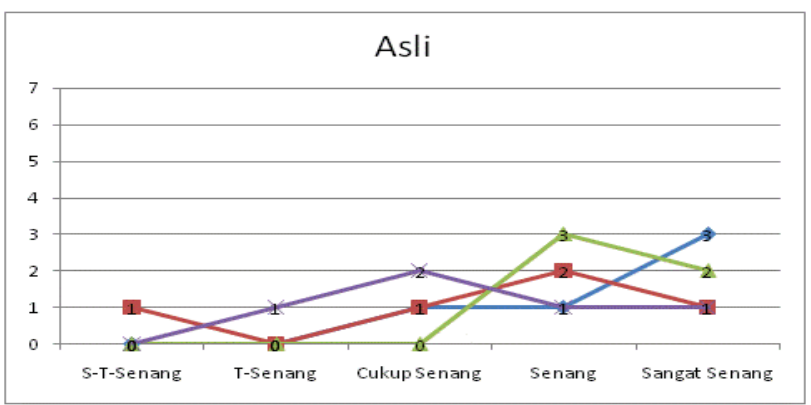

Gambar 4. Uji Persepsi Tuturan Asli Orang Kebanyakan

Gambar 4 merupakan hasil uji persepsi intonasi asli tuturan perasaan senang orang kebanyakan. Dari data gambar 4 ditunjukkan bahwa tuturan emosi senang orang kebanyakan sebanyak 7 responden memberikan persepsi senang.

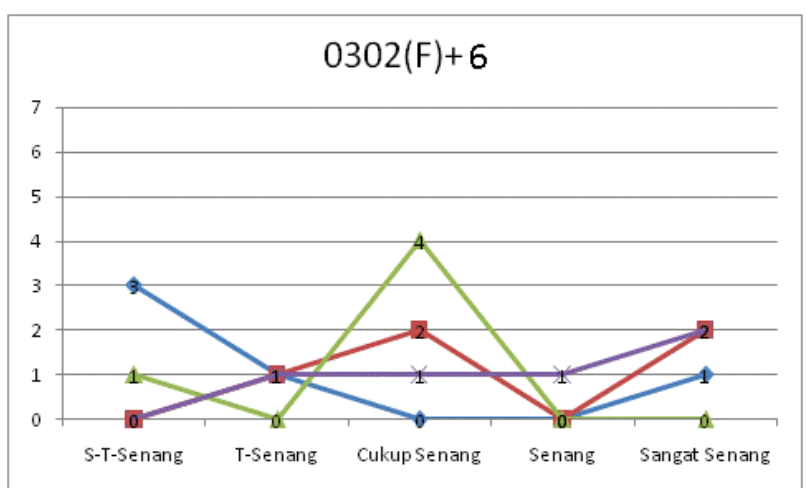

Gambar 5. Uji Persepsi Tuturan Orang Kebanyakan dengan Intonasi +6

Gambar 5 merupakan hasil uji persepsi intonasi +6 st tuturan emosi senang orang kebanyakan. Gambar 5 menunjukkan bahwa pada tuturan emosi senang dengan perubahan intonasi yang dinaikkan 6 st (0302B (F)+6). Uji ini diikuti oleh 8 responden yang memberikan persepsi senang dan 5 responden yang memberikan persepsi cukup senang.

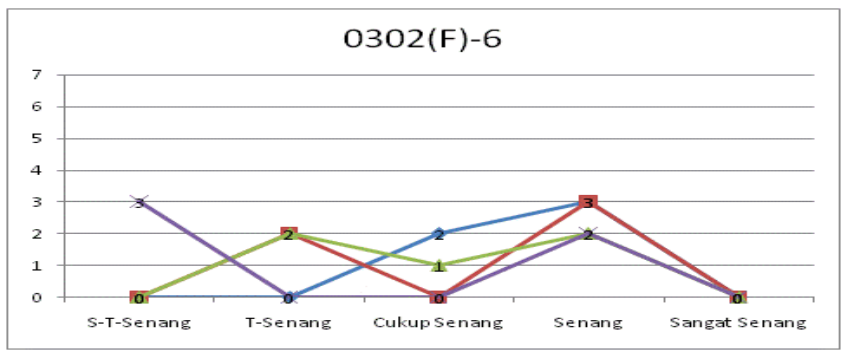

Gambar 6. Uji Persepsi Tuturan Orang Kebanyakan dengan Intonasi -6

Gambar 6 merupakan hasil uji persepsi -6 st tuturan emosi senang yang disampaikan oleh orang kebanyakan. Data tersebut menunjukkan tuturan emosi senang dengan perubahan intonasi yang diturunkan 6 st (0302E (F)-6). Adapun ini 
diujikan pada 10 responden yang memberikan persepsi senang, sedangkan 4 responden memberikan persepsi tidak senang.

Berdasarkan analisis data yang telah dilakukan dapat disimpulkan bahwa kontur nada salinan hasil formulasi pitch tier pada eksperimen 2 dengan menurunkan 3st, 4st, dan 6st maka alir nada tuturan asli 0301 A mempunyai skor nilai 151. Skor ini merupakan alir nada yang paling tinggi nilainya dibandingkan dengan tuturan salinan 0301E, 0301C dan 0301G pada tuturan emosi senang. Penurunan kontur pada nada tuturan pada tuturan salinan 0301E, 0301C dan 0301G emosi senang mempunyai skor nilai 120, 127 dan 122. Walaupun tuturan menunjukkan persepsi yang menurun, tetapi masih tetap menunjukkan makna emosi senang. Penaikan atau inklinasi kontur nada pada tuturan salinan 0301F, emosi senang merupakan alir nada yang paling rendah skor nilainya, yaitu 132 . Meskipun tuturan menunjukkan persepsi yang menurun, tetapi masih tetap menunjukkan makna emosi senang. Penaikan atau inklinasi kontur nada pada tuturan salinan 0301D dan 0301B, emosi senang merupakan alir nada yang berubah maknanya. Perubahan dari makna alir nada tuturan asli 0301A emosi senang menjadi makna emosi sangat senang dan mempunyai skor nilai 142 (0301D) dan skor nilai147 (0301B).

Dengan begitu, persepsi responden kalangan kaum bangsawan terhadap intonasi tuturan emosi senang kalangan kaum bangsawan adalah apabila frekuensinya dinaikkan dan diturunkan, persepsi responden adalah senang. Persepsi responden kalangan orang kebanyakan terhadap intonasi tuturan emosi senang kalangan kaum bangsawan adalah apabila frekuensi dinaikkan persepsi responden adalah senang. Jika frekuensi diturunkan, persepsi responden adalah cukup senang. Persepsi responden kalangan kaum bangsawan terhadap intonasi tuturan emosi senang kalangan orang kebanyakan adalah apabila frekuensi dinaikkan dan diturunkan, persepsi responden menjadi sama, yaitu senang. Persepsi responden kalangan orang kebanyakan terhadap intonasi tuturan emosi senang kalangan orang kebanyakan apabila frekuensi dinaikkan dan diturunkan, persepsi responden menjadi sama, yaitu cukup senang.

\section{SIMPULAN}

Alir nada senang bena amba mendengar kabarnya yo pada tuturan emosi senang [sənãí $\square$ benã amba məndeñãr kabaríã jo] yang dituturkan oleh kalangan kaum bangsawan menunjukkan alir nada turun sedangkan pada kalangan orang kebanyakan menunjukkan alir nada naik turun-naik turun. Namun demikian, keduanya sama-sama mempunyai kontur nada deklinasi. Perbandingan durasi tuturan intonasi emosi senang kalangan kaum bangsawan dan kalangan orang kebanyakan dapatlah disimpulkan bahwa lebih panjang durasi dari kalangan orang kebanyakan dibandingkan dengan kalangan kaum bangsawan. Adapun kontur nada (pitch contour) asli tuturan emosi senang kalangan kaum bangsawan dan kalangan kalangan orang kebanyakan yang dipersepsikan responden tidak menunjukkan perbedaan persepsi emosi senang yang signifikan. Tuturan emosi senang dari kalangan orang kebanyakan lebih tinggi dibandingkan dengan kalangan kaum bangsawan dan terdapat perbedaan durasi pada saat pengucapan. Dengan melakukan perubahan tuturan emosi senang, yaitu menurunkan beberapa st hasilnya masih tetap menunjukkan makna emosi senang, tetapi ketika dinaikkan beberapa st maka, hasilnya menjadi makna emosi sangat senang. 


\section{DAFTAR PUSTAKA}

Adisaputera, A. (2009). Potensi Kepunahan Bahasa Pada Komunitas Melayu Langkat di Stabat, Kabupaten Langkat, Sumatera Utara. Logat: Jurnal Ilmiah Bahasa dan Sastra, v(1), 45 - 55.

Al Baihaqi, S. (2015). Ekspresi Emosi Marah. Buletin Psikologi, 23(1), 22 - 30. https://doi.org/10.22146/bpsi.10574.

Alfarisi, S. (2017). Sistem Prediksi Penjualan Gamis Toko QITAZ Menggunakan Metode Single Exponential Smoothing. JABE (Journal of Applied Business and Economic), 4(1), 80 - 95. https://doi.org/10.30998/jabe.v4i1.1908.

Alviah, I. (2014). Kesantunan Berbahasa Dalam Tuturan Novel Para Priyayi Karya Umar Kayam. Seloka: Jurnal Pendidikan Bahasa dan Sastra Indonesia, 3(2), $128-135$.

Ardiana, D. P. Y., \& Loekito, L. H. (2018). Barang Menggunakan Metode Weighted Moving Average. Jurnal Teknologi Informasi dan Komputer, 4(1), $71-79$.

Ardipal, A. A. (2015). Kembalikan Lagu Anak-anak Indonesia: Sebuah Analisis Struktur Musik. Panggun: Jurnal Seni Budaya, 25(4), 343 - 355. https://doi.org/ 10.26742/panggung.v25i4.42.

Gofur, A. A., \& Widianti, U. D. (2015). Sistem Peramalan untuk Pengadaan Material Unit Injection di PT. XYZ. Komputa : Jurnal Ilmiah Komputer Dan Informatika, 2(2), 13 - 18. https://doi.org/ 10.34010/komputa.v2i2.86.

Handayani, L., \& Nurwidawati, D. (2013). Hubungan Pola Asuh dan Ekspresi Emosi Keluarga dengan Kekambuhan Pasien Skizofrenia di Rumah Sakit Jiwa Menur Surabaya. Jurnal Psikologi Teori dan Terapan, 4(1), 24 - 30. https://doi.org/ 10.26740/jptt.v4n1.p24-30.

Handono, S. (2017). Tindak Tutur dalam Iklan Berbahasa Jawa di Radio. Jalabahasa: Jurnal Ilmiah Kebahasaan, 13(1), 1 - 20. https://doi.org/ 10.36567/jalabahasa.v13i1.52.

Lidwina, S. (2012). Keterampilan Membaca dan Menulis. Jurnal STIE Semarang, $4(3), 9-16$.

Morrison, S. J., \& Fyk, J. (2011). Intonation. In The Science \& Psychology of Music Performance: Creative Strategies for Teaching and Learning. https://doi.org/10.1093/acprof:oso/9780195138108.003.0012

Mulyani, R., Barus, A., \& Muda, I. (2018). Local Wisdom of Merisik in Melayu Langkat Society: Oral Tradition Study. International Journal of Civil Engineering and Technology, 9(11), 2714-2720.

Nadhiroh, Y. F. (2015). Pengendalian emosi: Kajian Religio-psikologis tentang Psikologi Manusia. Saintifika Islamica: Jurnal Kajian Keislaman, 2(1), 53 63.

Nasir, Z. M., \& Hamzah, Z. A. Z. (2014). Sikap dan Motivasi Pelajar Terhadap Pembelajaran Bahasa Melayu. Procedia - Social and Behavioral Sciences, 134, 408 - 415. https://doi.org/10.1016/j.sbspro.2014.04.263

Nurlifa, A., \& Kusumadewi, S. (2017). Sistem Peramalan Jumlah Penjualan Menggunakan Metode Moving Average Pada Rumah Jilbab Zaky. INOVTEK Polbeng - Seri Informatika, 2(1), $18 \quad-\quad 25$. . https://doi.org/10.35314/isi.v2i1.112

Oktavia, W. (2018). Penamaan Bunyi Segmental dan Suprasegmental Pada Pedagang Keliling. Jurnal Bahasa Lingua Scientia, 10(1), 1 - $16 .$. https://doi.org/10.21274/1s.2018.10.1.1-16 


\section{Indonesian Language Education and Literature e-ISSN: 2502-2261 \\ http://www.syekhnurjati.ac.id/jurnal/index.php/jeill/ \\ Vol. 6, No. 1, Desember 2020, 47 - 57}

Poegoeh, D. P., \& Hamidah, H. (2016). Peran Dukungan Sosial dan Regulasi Emosi Terhadap Resiliensi Keluarga Penderita Skizofrenia. INSAN Jurnal Psikologi dan Kesehatan Mental, 1(1), 12 - $21 . \quad$. https://doi.org/10.20473/jpkm.v1i12016.12-21

Rahman, S. A. (2016). Prosodi 'Perkhidmatan' Amanat Ketua Setiausaha Negara. Proceedings of the ICECRS. https://doi.org/10.21070/picecrs.v1i1.556

Suciati, R., \& Agung, I. M. (2017). Perbedaan Ekspresi Emosi pada orang Batak, Jawa, Melayu dan Minangkabau. Jurnal Psikologi, 12(1), 99 - 108. https://doi.org/10.24014/jp.v12i2.3236

Tarigan, H. G. (2018). Berbicara sebagai suatu keterampilan bahasa. Bandung: Angkasa.

Zuhrah, F. (2016). Pergeseran Peran dan Posisi Ulama pada Masyarakat Melayu di Tanjung Pura Kabupaten Langkat. HIKMAH: Journal of Islamic Studies, 12(1), 107 - 140. http://dx.doi.org/10.47466/hikmah.v12i1.58 